\title{
EFFECTS OF CONCENTRATED FEED ENRICHED WITH ZEOLITE AND GLYCERIN ON PRODUCTIVITY OF BEEF CATTLE
}

\author{
A.Erdenechimeg, A.Otgonjargal, N.Togtokhbayar* \\ School of Animal Science and Biotechnology, Mongolian University of Life Sciences, \\ Ulaanbaatar, Mongolia
}

*Corresponding author:n.togtokhbayar@muls.edu.mn

\begin{abstract}
Sixteen native breeds of cattle $(n=16)$ were selected as experimental animal and divided into two control and two experimental group. The cattle for this study were two months old native breeds that all castrated males with average live weight $270 \pm 5 \mathrm{~kg}$. During the experimental period cattle in first control group were grazed on open pasture, while second control group were kept in door and fed by well-balanced concentrated feed for beef cattle. However first experimental group were fed by feed ration enriched with $2 \%$ of native zeolite, whereas second experimental group was provided by ration with $2 \%$ of zeolite and $6 \%$ of glycerin. All of these cattle in two different groups were fed for 52 days in total, which divided into preparation and experimental periods of 7 and 45 days. Daily body weight of cattle in first control group was declined by 15 $\mathrm{kg}(357.5 \mathrm{~g})$ while it was increased by $22.25 \mathrm{~kg}(530 \mathrm{~g})$ in second control, $30.04 \mathrm{~kg}(714.5 \mathrm{~g})$ in first experimental and $24.75 \mathrm{~kg}(589.3 \mathrm{~g})$ in second experimental groups $(p<0.001)$.
\end{abstract}

KEY WORDS: Digestibility, metabolizable energy, growth, meat productivity

\section{INTRODUCTION}

The Mongolian herds well adapted to the extreme climate and survived during winter and spring via losing weight obtained in summer and autumn. Winter and spring feed availability on the pastures decreases by $60-70 \%$, nutritive value of pasture plants declines by $50-60 \%$ and grazing time of animals is shortening by $4-6$ hours. Therefore, Mongolian livestock losses their weight up to $25-30 \%$ of summer weight if not supplementary feeing [5]. Mongolia rises 4.04 million of head cattle which accounts $6.63 \%$ in total number of livestock in 2017. The success of any animal production depends on proper nutrition and feeding program. The key to a good feeding program for beef cattle is to have the animals gaining weights at the proper rate to reach target weight and condition at show time. There is concentrated feed for beef cattle, produced by Altan taria company, which is enriched with minerals however there is no evidence that adding zeolite, glycerin and their mixture to beef cattle feed in Mongolia. Glycerin consistently decreases acetate:propionate ratio, and may have inhibitory effects on fibre digestion, which is mediated via its inhibitory effects on some microbial populations. Concentrations less than 10 percent of the diet dry matter yield favourable biological responses in cattle, whereas levels in excess of 10 percent may have deleterious consequences for feed intake and growth of cattle [28]. Also zeolite given to piglets as a feed additive (2\%) since weaning and throughout the fattening period caused a significant increase in weight gain and a noticeable increase in feed conversion [4]. The aim of this study was to investigate the effect of concentrated feed for beef cattle enriched with glycerin and zeolite source on feed intake, weight gain performance. 


\section{MATERIALS AND METHODS}

Compound feed for beef cattle was produced at Bayalag-Emeelt feed processing factory located in Khan-Uul district of the Ulaanbaatar and feeding trial was conducted in November 2014 Bayan Simmental beef farm situated in Bayan sum $\left(43^{\circ} 34^{\prime} 15^{\prime}\right.$ 'N, $\left.104^{\circ} 25^{\prime} 33^{\prime \prime} \mathrm{E}\right)$ of Tuv province. Two years old, sixteen Mongolian native cattle with live weight approximately $250 \mathrm{~kg}$ were selected and divided into two control and two experimental groups. Selected cattle were fed by experimental feed for preparation and experimental periods. The experimental feed was applied to cattle four times a day (twice in the morning and afternoon, respectively) and animal had free access to pure water during the experimental period. Feed was placed in feeding pots and applied to each cattle individually. Experimental feed was formulated from mixtures of concentrated feed and natural hay grass. These feed mixtures varied differently along the feeding experimental periods. At first period the feed were comprised ratio of 70:30 percentage of concentrated feed and hay, respectively while it was $60: 40 \%$ at middle. Moreover at last period, it was balanced by 50:50 percentage of above mentioned two main feed ingredients. Chemical composition of these feed were used for the experiment is shown at the table 1.

Table 1.

Chemical composition of concentrated feed enriched with zeolite and glycerin (absolute dry matter basis, \%)

\begin{tabular}{llcccccc}
\hline № & Feed types & $\begin{array}{c}\text { Organic } \\
\text { matter }\end{array}$ & $\begin{array}{c}\text { Crude } \\
\text { protein }\end{array}$ & $\begin{array}{c}\text { Crude } \\
\text { fat }\end{array}$ & $\begin{array}{c}\text { Crude } \\
\text { fiber }\end{array}$ & $\begin{array}{c}\text { Ether } \\
\text { extract }\end{array}$ & $\begin{array}{c}\text { Crude } \\
\text { ash }\end{array}$ \\
\hline 1 & Hay & 95.47 & 9.47 & 2.0 & 34.28 & 49.73 & 4.53 \\
2 & $\begin{array}{l}\text { Compound feed } \\
\text { Compound feed with zeolit }\end{array}$ & 96.13 & 12.85 & 1.64 & 6.9 & 74.73 & 3.87 \\
3 & $\begin{array}{l}2 \% \\
\text { Compound feed with zeolit }\end{array}$ & 91.87 & 14.82 & 1.90 & 5.62 & 69.54 & 8.13 \\
4 & 93.89 & 13.45 & 5.46 & 5.98 & 79.01 & 6.11 \\
\hline & SEM glycerin 6\% & 1.15 & 0.90 & 0.53 & 1.28 & 2.72 & 1.07 \\
\hline
\end{tabular}

Feed intake, body weight and daily gain, slaughter yield of experimental cattle was determined.

The average daily gain (ADG) obtained was calculated as follows:

$$
A D G=\frac{F L W-I L W}{\text { no. of days in the period }}
$$

Where FLW is the final live weight and ILW is the initial live weight of each period.

Crude protein was determined using Kjeldahl procedure (AOAC 988.05), total fiber content in an ANKOM 200 fiber analyzer (AOAC 962.09) and dry matter, organic matter concentrations by drying sample material at $105^{\circ} \mathrm{C}$ as well as total ash content by incinerating at $550^{\circ} \mathrm{C}$ (AOAC 942.05) in Animal feed evaluation laboratory of School of Animal
Science and Biotechnology, Mongolian University of Live Science. Organic matter digestibility and metabolizable energy were calculated by fiber index method formulated by Gendaram [6]. The statistical data analysis was performed in SPSS version 16.0 for Windows (IBM Corp., 2011) with a two-tailed significance level of $\mathrm{p} \leq 0.05$. 


\section{RESULTS}

The crude protein, fat and crude ash in concentrated feed enriched by natural zeolite was increased by 2 , 0.03 and $4.3 \%$, respectively while organic matter, total fiber and ether extracts were decreased by 4.3 ,
1.3 and $5.2 \%$, respectively. Generally, crude protein, fat and total ash contents of the concentrated feed enriched with natural zeolite and glycerin was increased whereas the fiber content was declined.

Table 2 .

Organic matter digestibility and metabolizable energy of enriched concentrated feed

\begin{tabular}{llcc}
\hline № & Feed types & Digestibility, \% & Metabolizable energy, MJ \\
\hline 1 & Hay & 54.06 & 6.13 \\
2 & Compound & 84.02 & 12.13 \\
& Compound feed with zeolit 2 & 85.16 & 12.53 \\
& $\%$ & & 12.35 \\
& $\begin{array}{l}\text { Compound feed with zeolit } 2 \\
\text { \%+glycerin 6 \% }\end{array}$ & 84.84 & 0.26 \\
\hline
\end{tabular}

Digestibility of the compound feed for fattening beef cattle was increased by $1.1 \%$ and $0.8 \%$, and metabolizable energy by $0.22 \mathrm{MJ}, 0.4 \mathrm{MJ}$ when natural zeolite alone and mix of zeolite and glycerin added feed, respectively. Feed intake of beef cattle: Intake were improved during the fattening period while compound feed was ingested $100 \%$ by experimental cattle.

Table 3.

\section{Hay intake}

\begin{tabular}{|c|c|c|c|c|c|c|}
\hline \multirow[b]{2}{*}{ Treatments } & \multicolumn{2}{|c|}{ Initial } & \multicolumn{2}{|c|}{ Middle } & \multicolumn{2}{|c|}{ Final } \\
\hline & Intake, $\%$ & SD.E & Intake, $\%$ & SD.E & Intake, $\%$ & SD.E \\
\hline Control-II & 42.75 & 0.47 & $66.70^{\mathrm{a}}$ & 3.20 & $72.54^{\mathrm{ab}}$ & 2.96 \\
\hline Experiment -I & 41.11 & 3.02 & $61.14^{\mathrm{ab}}$ & 3.46 & $78.39^{\mathrm{a}}$ & 0.56 \\
\hline Experiment -II & 43.47 & 0.23 & $55.70^{\mathrm{c}}$ & 0.82 & $69.28^{c}$ & 1.93 \\
\hline $\mathrm{P}$ & ns & & $*$ & & $*$ & \\
\hline
\end{tabular}

significant differences between different stages of the treatments.

From the table 3, hay intake of experimental feed was $41-43 \%$ in all groups $(\mathrm{P}>0.05)$ during the initial stage of treatment. Hay intakes of different feed in three groups were significantly increased from initial to final and the highest intakes were found at the final stage of experiment.

The growth and meat productivity: The absolute and relative growth and daily weight gain are the most relevant indicators to measure meat production. 
Table 4.

Body weight gain of beef cattle, $\mathrm{kg}$

\begin{tabular}{|c|c|c|c|c|c|c|}
\hline \multirow[b]{2}{*}{ Groups } & \multicolumn{2}{|c|}{ Initial } & \multicolumn{2}{|c|}{ Middle } & \multicolumn{2}{|l|}{ Final } \\
\hline & Body weig & SD.E & Body weight,kg & SD.E & Body weight, kg & SD.E \\
\hline Control-I & 277.75 & 2.78 & $273.25^{\mathrm{b}}$ & 3.25 & $262.75^{\mathrm{b}}$ & 0.85 \\
\hline Control-II & 278.25 & 2.87 & $290.50^{\mathrm{a}}$ & 2.75 & $300.50^{\mathrm{a}}$ & 6.09 \\
\hline Experimental -I & 276.25 & 0.63 & $292.0^{\mathrm{a}}$ & 1.22 & $306.25^{\mathrm{a}}$ & 1.19 \\
\hline Experimental -II & 276.75 & 2.29 & $286.5^{\mathrm{a}}$ & 3.07 & $301.50^{\mathrm{a}}$ & 2.53 \\
\hline $\mathrm{P}$ & ns & & $* * *$ & & $* * *$ & \\
\hline
\end{tabular}

Beef cattle kept in first control group were lost their $22.2 \mathrm{~kg}, 30 \mathrm{~kg}$ and $24.7 \mathrm{~kg}$, respectively during the body weight by $15 \mathrm{~kg}$ while ones in second control, experimental period $(\mathrm{p}<0.001)$.

first and second experimental groups were gained by

Table 5.

Daily weight gains and growth of beef cattle

\begin{tabular}{|c|c|c|c|c|c|c|}
\hline Groups & $\begin{array}{l}\text { Absolute } \\
\text { growth, kg }\end{array}$ & SD.E & $\begin{array}{l}\text { Relative } \\
\text { growth, \% }\end{array}$ & SD.E & $\begin{array}{l}\text { Daily weight } \\
\text { gain, g }\end{array}$ & SD.E \\
\hline Control-I & $-15.0^{c}$ & 3.49 & $-5.4^{\mathrm{c}}$ & 1.18 & $-357.5^{\mathrm{c}}$ & 0.08 \\
\hline Control-II & $22.25^{\mathrm{ab}}$ & 3.67 & $7.99^{\mathrm{ab}}$ & 1.26 & $530.0^{\mathrm{b}}$ & 0.09 \\
\hline Experimental -I & $30.0^{\mathrm{a}}$ & 1.09 & $10.86^{\mathrm{a}}$ & 0.40 & $714.5^{\mathrm{a}}$ & 0.03 \\
\hline Experimental -II & $24.75^{\mathrm{ab}}$ & 0.48 & $8.94^{\mathrm{ab}}$ & 0.15 & $589.3^{\mathrm{b}}$ & 0.01 \\
\hline $\mathbf{P}$ & $* * *$ & & $* * *$ & & $* * *$ & \\
\hline
\end{tabular}

Negative relative growth was found among beef cattle improvements of relative growth in these three groups kept in first control group whereas weight gain were similar; the highest growth was occurred in first observed in other tree groups. However, experimental group.

Table 6.

Slaughter yields for beef cattle

\begin{tabular}{|c|c|c|c|c|c|c|c|c|c|c|}
\hline \multirow[b]{2}{*}{ Groups } & \multirow{2}{*}{$\begin{array}{l}\text { After train } \\
\text { weight, } \mathrm{kg}\end{array}$} & \multirow[b]{2}{*}{ SD.E } & \multirow{2}{*}{$\begin{array}{l}\text { Carcass, } \\
\mathrm{kg}\end{array}$} & \multirow[b]{2}{*}{ SD.E } & \multirow[t]{2}{*}{ Fat, kg } & \multirow[b]{2}{*}{ SD.E } & \multirow{2}{*}{$\begin{array}{l}\text { Slaughter } \\
\text { weight, } \mathrm{kg}\end{array}$} & \multirow[b]{2}{*}{ SD.E } & \multicolumn{2}{|c|}{ Slaughter yield, } \\
\hline & & & & & & & & & & SD.E \\
\hline Control-I & $259 b$ & 0.5 & $123^{b}$ & 0.02 & $1.80^{\mathrm{b}}$ & 0.32 & $124.84^{c}$ & 0.03 & $48.20^{\mathrm{c}}$ & 0.78 \\
\hline Control-II & $290.68 \mathrm{a}$ & 6.74 & $143.43^{\mathrm{a}}$ & 4.11 & $2.00^{\mathrm{b}}$ & 0.08 & $145.43^{b}$ & 3.99 & $50.03^{b}$ & 0.78 \\
\hline $\begin{array}{l}\text { Experimental } \\
\text {-I }\end{array}$ & 293.32 & 1.70 & $152.50^{\mathrm{a}}$ & 1.25 & $2.67^{\mathrm{a}}$ & 0.31 & $155.59^{\mathrm{a}}$ & 1.50 & $53.04^{\mathrm{a}}$ & 0.30 \\
\hline $\begin{array}{l}\text { Experimental } \\
\text {-II }\end{array}$ & $291.68 \mathrm{a}$ & 1.31 & $145.75^{\mathrm{a}}$ & 0.25 & $2.00^{\mathrm{b}}$ & 0.108 & $148.52^{b}$ & 0.12 & $50.92^{\mathrm{b}}$ & 0.62 \\
\hline$P$ & $* * *$ & & $* * *$ & & $* * *$ & & $* * *$ & & $* * *$ & \\
\hline
\end{tabular}


From the table 6, slaughter weights were $124.84 \mathrm{~kg}$, $145.43 \mathrm{~kg}, 155.59 \mathrm{~kg}$ and $148.52 \mathrm{~kg}$ in first and second controls, first and second experimental groups. In other word, slaughter yields were $48.2 \%$, $50.9 \%$, and $53 \%, 50.9 \%$ in first, second control and

\section{DISCUSSION}

Chemical composition and nutrient value of beef cattle: Tsedev [19], Otgoo [12], Asuren and Sanchir [1], Gendaram and Togtokhbayar [6], Byambasaikhan and Rinchindorj [15], Gurbazar [4] and Rentsenkhand [16] were conducted studies on concentrated feed for different types of animals in Mongolia. The crude protein, crude fat and extract ether contents of diet used in present study was higher by $0.8 \%, 3.7 \%$ and $0.3 \%$ in comparison to composition of concentrated feed consisted from $34 \%$ bran, $14 \%$ wheat, $10 \%$ barley, $10 \%$ oat, $30 \%$ straw and $2 \%$ salt by Tsedev [19]. Organic matter digestibility and metabolizable energy of enriched concentrated feed used present study was higher by $15.4 \%$ and 0.2 MJ than findings by Tsedev [19]. These parameters were higher by $16.2 \%$ and $0.3 \mathrm{MJ}$ comparing results from Rentsenkhand [16]. These inconsistences can be explained by balancing metabolizable energy of concentrated feed in enriching with protein and minerals.

Growth and meat productivity of beef cattle: Studies on different feeding and management options for beef cattle in Mongolia were conducted by Javzmaa [8] in crossbred of native Mongolian and Kazakian white head breed, by Tserendulam [19] and Gonchig [3] in Simmental heifer, by Tsedev [19], Gombodorj [2] in crossbred of Mongolian native with Kazakian white head breed, Nergui [10], in growing calves of Kazakian white head and Selenge breeds, by Rinchindorj [14] and Tumenbayar [18] in Selenge breed, by Dorjbat [7] in Mongolian breed of cattle.

\section{CONCLUSIONS}

- Cattle kept in door and fed by experimental feed gained while grazing cattle lost their body weight by $15 \mathrm{~kg}$

- Natural zeolite and glycerin addition to growing beef has significance not only to supply mineral requirement of cattle, improve efficiency of first, second experimental groups. The feed applied to beef cattle kept in first experimental group showed the highest positive effects on slaughter weight and slaughter yield $(p<0.001)$. The lowest once were found in first control group.

An addition of natural zeolite to feed ration has resulted on digestibility of various nutrients and metabolic function of the animal. The zeolite added by 3,5 and $8 \%$ into total ratio's dry matter has increased digestibility of nutrients by $1.27-6.33 \%$, daily body gain by $15.22-23.48 \%$, although feed intake was declined by $14.86-19.57$ as reported by Renchindorj and he suggested that $5 \%$ zeolite addition to feed ratio has the highest result to increase feed efficiency [27]. Found that up to $18 \%$ of glycerin addition to feed ratio showed improvement in feed efficiency and energy supplement [26]. When glycerin added to feed by 4,8 and $12 \%$ of total feed ration, live weight of beef in feedlot was increased by $125 \mathrm{~kg}$ after 90 days and $12 \%$ of glycerin addition showed no negative effects on rumen fermentation, metabolism and meat quality [22]. Daily weight gain in present study was higher by $165.5 \mathrm{~g}, 163.3 \mathrm{~g}, 8.5$ $\mathrm{g}, 105.9 \mathrm{~g}$ and $108.4 \mathrm{~g}$ than results determined by Dorjbat [7], Javzmaa [8], Tserendulam [21], Gombodorj [2] and Rinchindorj [14]. Nevertheless, daily weight gain resulted by Tumenbayar was higher by $63.5 \mathrm{~g}$ that finding by us. These differences in growth were most probably due to productivity of breeds. Slaughter yield of beef cattle in this study was greater than these measured by Tumenbayar [18], Dorjbat [7], Gombodorj [2] and Gonchig [3]. This result may be obtained due to feed enrichment by zeolite and glycerin. There is big potential to increase meat production of growing cattle when feed them well balanced feed ration.

nutrients of the feed also improve digestibility of nutrients and increase meat production. Therefore, our results suggest that $2 \%$ zeolite and $6 \%$ glycerin addition to total dry weight of the feed is most suitable. 


\section{REFERENCE}

[1]Asuren D., Sanchir Ch., (1980) Animal feeding manual with feedstuff enriched with caragana., UB., 2-4 (in Mongolian)

[2] Gombodorj. J., (1979) Crossbreeding experiment among Mongolian native breed cattle and Kazakh breed in the field of Mongolia., 11-17., (in Mongolian)

[3] Gonchig D., (1975) Cattle fattening findings using remote and reserved pastures (in Mongolian)

[4] Gurbazar D., (2016) The issue of feed preparation of some species for undersirable plants. Doctoral degree dissertation., 3-4 (in Mongolian)

[5] Gendaram Kh., (1977) Chemical compositions and dynamics of nutritive values of the plants in steppe pastures. Candidate of science doctoral degree dissertation., 25-77, (in Mongolian)

[6] Gendaram Kh., (1995) Accelerated method for feed evaluation., Approved by scientific committee on livestock training and research institute, MULS on 7 th December 1995 (in Mongolian)

[7]Dorjbat Yo., (2005) Potentials to fattening growing beef for supplying meat products during the cold season. Doctoral degree dissertation, (in Mongolian)

[8] Jawjmaa R., (1983Scientific research finding on new breed of beef creating potentials in forest steppe zone of Republic of Mongolia. (in Mongolian)

[9] Nergui D., (1976) Temporary technology for herding and fattening growing beef. Doctoral degree dissertation., 83-85 (in Mongolian)

[10] Nergui D., (1976) Өсвөр үхэр өсгөн бойжуулах, шахаж бордох түр технологи.

[11] Nergui D., Jigjidpurev. S., (2011) “Animal feed and feeding research. Review for the 50th anniversary of the Mongolian Institute of Animal Husbandry." UB, 11-15 (in Mongolian)

[12] Otgoo Ts., (1986) Experimental result on feeding sheep with mixed feedstuff. 3-5 (in Mongolian)

[13] Rinchindorj D., (1992) Enhancing reproductivity of breeding cow of Selenge breed via raising intensively and using her genetic resources Selenge breed. Candidate of science doctoral degree dissertation., (in Mongolian)
[14] Rinchindorj D., (1996) Raising and fattening feed rations for hybrid beef calves, Doctoral degree dissertation., 75-76 (in Mongolian)

[15] Rinchindorj D., Byambasaikhan D., (2004) Chemical composition and nutritive values of reserved hay-grass in national reserve fund., Bacherol degree dissertation (in Mongolian)

[16] Rentsenkhand J., (2017) The results of feed ration development and its enrichment with zeolite, glycerol and yeast., Doctoral degree dissertation., 10-65 (in Mongolian)

[17] Togtokhbayr N., (2005) Issues on evaluating animal feed nutrition via metabolizable energy. Doctoral degree dissertation, 5-96 (in Mongolian)

[18] Tumenbayr P., (2008) Some issues to rapidly fatten growing beef., Master degree dissertation., (in Mongolian)

[19] Tsedev D., (1980) Experimental findings on developing rations of complexed feedstuff for fattening beef, Doctoral degree dissertation., 8394 (in Mongolian)

[20] Tsedev D., (1968) Methodologies to prepare mixed feedstuffs in Republic of Mongolia, UB.,5-11 (in Mongolian)

[21] Tserendulam R., (1980) Tables for nutritive values of variety of feed., УБ., 11-34 (in Mongolian)

[22] Tserendulam R., (2011) Animal feed for Mongolia., UB., 98-100 (in Mongolian)

[23] Anderson.V.L, Ilse. B.R, (2014) Effect of Glycerol Level in Feedlot Finishing Diets on Animal Performance., 63-67 (in Mongolian)

[24] AOAC., (1990) Official methods of analysis, $15^{\text {th }}$ Edition., Association of Official Analytical Chemists., USA, 5-9

[25] Breck D.W., (1974) Zeolite molecular sieves: structure, chemistry, and use. John Wiley and Sons, New York

[26] Drouillard J.S., (2012) Utilization of crude glycerin in beef cattle. Biofuel co-products as livestock feed Opportunities and challenges, 155-161

[27] Eiras. C.E, Barbosa.L.P, Marques.J.A,. Araújo. F.L, Limaa. B.S, Zawadzki. F, Perottoc. D, Pradoa.I.N, (2014) Glycerine levels in the diets 
of crossbred bulls finished in feedlot: Apparent digestibility, feed intake and animal performance. Animal Feed Science and Technology, 222-226

[28] Lage.J.F, Paulino. P.V.R, Pereira. L.G.R., Duarte. M.S, Valdares Filho S.C, Oliveira. A.S, Souza.N.K.P， Lima.J.C.M， (2014) Carcass characteristics of feedlot lambs fed crude glycerin contaminated with high concentrations of crude fat, Meat Science 96., 109-112

[29] March.N, Bach.A, Devant. M (2010) Effects of crude glycerin supplementation on performance and meat quality of Holstein bulls fed highconcentrate diets., Journal of animal Science., 101-104 